\title{
PENYUSUNAN ROAD MAP REFORMASI BIROKRASI DALAM MEWUJUDKAN WORLD CLASS GOVERNMENT DI KABUPATEN KEPULAUAN TANIMBAR PROVINSI MALUKU
}

\author{
Oleh \\ Yosinta Swarty Ganwarin', \\ Sadu Wasistiono ${ }^{2,}$ Eko Budi Santoso ${ }^{3}$ \\ 1) Pemerintah Daerah Kepulauan Tanimbar \\ Program Magister Terapan Studi Pemerintahan Daerah Institut Pemerintahan Dalam Negeri \\ sintaganwarin99@gmail.com \\ ${ }^{2,3)}$ Institut Pemerintahan Dalam Negeri
}

\begin{abstract}
PREPARATION OF A ROAD MAP FOR BUREAUCRATIC REFORM IN REALIZING WORLD CLASS GOVERNMENT IN THE TANIMBAR ISLAND REGENCY, , MALUKU PROVINCE

$T_{t}$ pursue the vision of bureaucratic ref to pursue the vision of bureaucratic reform of the Indonesian Government, namely "realizing world-class government" and the goal of bureaucratic reform "realizing good governance", it is deemed necessary to develop a Road Map Bureaucratic Reforming as a form of operationalization of the Grand Design 2010-2025 Bureaucratic Reform. In the Tanimbar Islands Regency, the preparation of the Road Map 20202024 Bureaucratic Reform has not been carried out, so that part of the Organization and Administration Section of the Regional Secretariat of the Tanimbar Islands Regency as the OPD in charge of the preparation of the Road Map needs to take action in realizing this matter. This study aims to analyze and determine the preparation of the Road Map for Bureaucratic Reform in realizing World Class Government, analyzing and knowing the supporting and inhibiting factors as well as analyzing and knowing the preparation strategy Road Map. This study used qualitative research methods with a descriptive approach. The determination of informants in this study was carried out by using the purposive sampling technique. The data collection technique is done by interview, observation, and documentation. The data analysis technique used is to use the SWOT analysis method. The results showed that the preparation of Road Map the Bureaucratic Reforming realizing World Class Government in the Tanimbar Islands Regency has not been implemented because there are still several obstacles such as the absence of underlying regional regulations, the existence of sectoral egos between regional apparatus organizations, inadequate infrastructure, budget constraints, lack of support from stakeholders, and low accountability and capability of human resources. Therefore, in this study the authors analyzed the strategies that can be done by local governments, namely utilizing the potential of adequate ASN in supporting the implementation of bureaucratic tasks, and utilizing the attention of the central and provincial governments to the construction of Masela Block.
\end{abstract}

Keywords: world-class government, road map, bureaucratic reform 


\section{ABSTRAK}

$\mathrm{D}^{\mathrm{s}}$ alam rangka mengejar visi reformasi birokrasi Pemerintahan Indonesia, yaitu "terwujudnya pemerintahan kelas dunia" dan tujuan reformasi birokrasi "mewujudkan tata kelola pemerintahan yang baik", maka dipandang perlu untuk menyusun Road Map Reformasi Birokrasi sebagai bentuk operasionalisasi dari Grand Design Reformasi Birokrasi 2010-2025. Di Kabupaten Kepulauan Tanimbar, penyusunan Road Map Reformasi Birokrasi 2020-2024 belum terlaksana, sehingga Bagian Organisasi dan Tata Laksana Setda Kabupaten Kepulauan Tanimbar sebagai OPD penanggung jawab penyusunan Road Map tersebut perlu untuk mengambil tindakan dalam mewujudkan hal yang dimaksud. Penelitian ini bertujuan untuk menganalisis dan mengetahui penyusunan Road Map Reformasi Birokrasi dalam mewujudkan World Class Government, menganalisis dan mengetahui faktor pendukung dan penghambat serta menganalisis dan mengetahui strategi penyusunan Road Map tersebut. Penelitian ini menggunakan metode penelitian kualitatif dengan pendekatan deskriptif. Penentuan informan dalam penelitian ini dilakukan dengan teknik purposive sampling. Teknik pengumpulan data dilakukan dengan wawancara, observasi dan dokumentasi. Teknik analisis data yang digunakan adalah dengan menggunakan metode analisis SWOT. Hasil penelitian menunjukkan bahwa penyusunan Road Map Reformasi Birokrasi dalam mewujudkan World Class Government di Kabupaten Kepulauan Tanimbar belum terlaksana karena masih terdapat beberapa kendala seperti belum adanya peraturan daerah yang mendasari, adanya ego sektoral antar OPD, sarana prasarana kurang memadai, keterbatasan anggaran, kurangnya dukungan dari stakeholder, serta akuntabilitas dan kapabilitas SDM Aparatur yang masih rendah. Oleh karena itu, dalam penelitian ini penulis menganalisis strategi yang dapat dilakukan pemerintah daerah, yaitu memanfaatkan potensi ASN yang memadai dalam menunjang pelaksanaan tugas birokrasi, dan memanfaatkan perhatian pemerintah pusat dan provinsi terhadap pembangunan Blok Masela.

Kata kunci: pemerintahan kelas dunia, peta jalan, reformasi birokrasi

\section{PENDAHULUAN}

$\mathrm{R}_{\mathrm{s}}^{\mathrm{e}}$ eformasi birokrasi merupakan langkah awal sebuah negara untuk mencapai kemajuan negaranya. Melalui reformasi birokrasi, pemerintah dapat melakukan upaya untuk mencapai good governance dengan mengubah sistem penyelenggaraan pemerintahan menjadi efektif dan efisien. Dalam rangka mengejar visi reformasi birokrasi Pemerintahan Indonesia, yaitu "terwujudnya pemerintahan kelas dunia" dan tujuan reformasi birokrasi "mewujudkan tata kelola pemerintahan yang baik" sesuai dengan Grand Design Reformasi Birokrasi 20102025 yang dimuat dalam Peraturan Presiden Republik Indonesia No. 81 Tahun 2010, maka dipandang perlu untuk menjalankan program reformasi birokrasi pada delapan area perubahan yang telah ditetapkan, yaitu kelembagaan (organisasi), peraturan perundang-undangan, Sumber Daya Manusia, pengawasan, akuntabilitas, tata laksana, pelayanan publik, dan pola pikir, budaya kerja dan manajemen perubahan di seluruh Kementerian/ Lembaga/Pemerintah Daerah.

Ilham dan Rahmadanita (2019: 46) mengatakan bahwa:

Pada dasarnya Reformasi Birokrasi adalah suatu perubahan signifikan elemen-elemen birokrasi seperti kelembagaan, sumber daya manusia aparatur, ketatalaksanaan, akuntabilitas, aparatur, pengawasan dan pelayanan publik, yang dilakukan secara sadar untuk memosisikan diri (birokrasi) kembali, dalam rangka menyesuaikan diri dengan dinamika lingkungan yang dinamis.

Tujuan jangka Panjang pelaksanaan reformasi birokrasi dapat dilihat pada gambar berikut ini. 


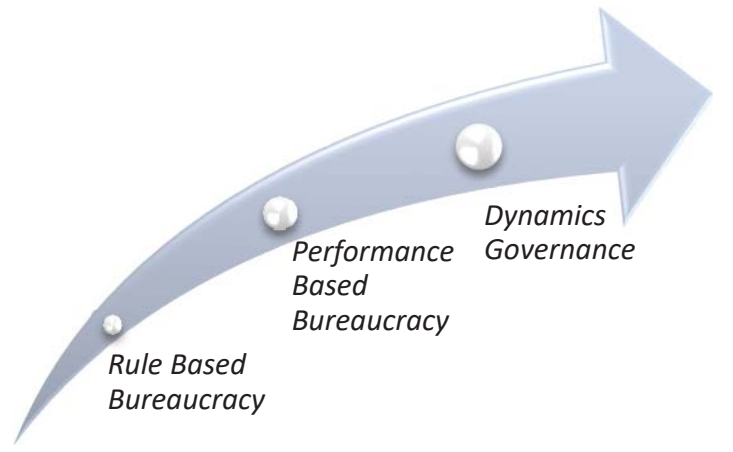

Gambar 1

Tujuan Jangka Panjang Pelaksanaan Reformasi Birokrasi (Sumber: Road Map Reformasi Birokrasi 2015-2019)

Tujuan jangka panjang pelaksanaan reformasi birokrasi pada 2025 di Indonesia, diharapkan pemerintahan sudah beranjak dari birokrasi berbasis kinerja menuju pada tatanan pemerintahan yang dinamis. Pemerintahan yang dinamis (dynamics governance) menjadi kunci jawaban dalam menghadapi berbagai tantangan pada era globalisasi dan perkembangan teknologi yang tiada hentinya.

Perubahan yang terjadi saat ini salah satunya adalah di bidang industri. (Wasistiono dan Anggraini, 2019: 79) mengemukakan pendapat bahwa:

Schwab (2017), for example, rolled out the concept of "industrial revolution 4.0" which is currently a discussion topic for various groups in the world. Schwab, in another book with Davis (2018), came with the concept of "agile governance" or agility in facing changes so that it leads to better governance. In dealing with changes, that are difficult to predict, it is not enough to carry out good and dynamic governance, but also to anticipate them with agility.

Good Governance, Dynamic Governance dan Agile Governance adalah tiga paradigma yang ada di dalam pemerintahan di mana memiliki keterkaitan satu dengan yang lain. Karena untuk menyesuaikan dengan perubahan yang terus terjadi, paradigma good governance dan dynamic governance tidaklah cukup. Perlu adanya penyempurnaan pemerintahan yang gesit, yaitu agile governance sehingga dapat terwujudnya tata kelola pemerintahan yang lebih baik (better governance).

Dalam era globalisasi yang sarat dengan perkembangan ilmu pengetahuan dan teknologi, persaingan dan tantangan serta untuk mencapai efektivitas dan efisiensi dalam penyelenggaraan sistem pemerintahan, menuntut agar terjadinya reformasi sistem pemerintahan termasuk birokrasinya, sehingga terjadi interaksi antar negara yang kemudian mendorong munculnya konsep pemerintahan kelas dunia (world class government). Di Negara Indonesia, telah ditargetkan pada 2025 Pemerintahan Indonesia akan menjadi Pemerintahan Kelas Dunia. Konsep pemerintahan kelas dunia dapat dilihat pada Gambar 2.

Pelaksanaan reformasi birokrasi membutuhkan Grand Design dan Road Map sebagai living document yang dapat dipahami dan dilaksanakan oleh seluruh pihak dan stakeholder yang berkepentingan dalam mengikuti dinamika perubahan sistem penyelenggaraan pemerintahan. Pelaksanaan reformasi birokrasi melalui Road Map Reformasi Birokrasi telah memasuki sasaran 5 (lima) tahun terakhir, yakni pada periode 2020-2024. Road Map Reformasi Birokrasi menurut Peraturan Menteri Pendayagunaan Aparatur Negara dan Reformasi Birokrasi Republik Indonesia No. 25 Tahun 2020 merupakan bentuk operasionalisasi Grand Design Reformasi Birokrasi dan rencana rinci Reformasi Birokrasi selama 5 (lima) tahun, yaitu tahun 2020-2024, dan akan mengedepankan asas "Fokus dan Prioritas". 


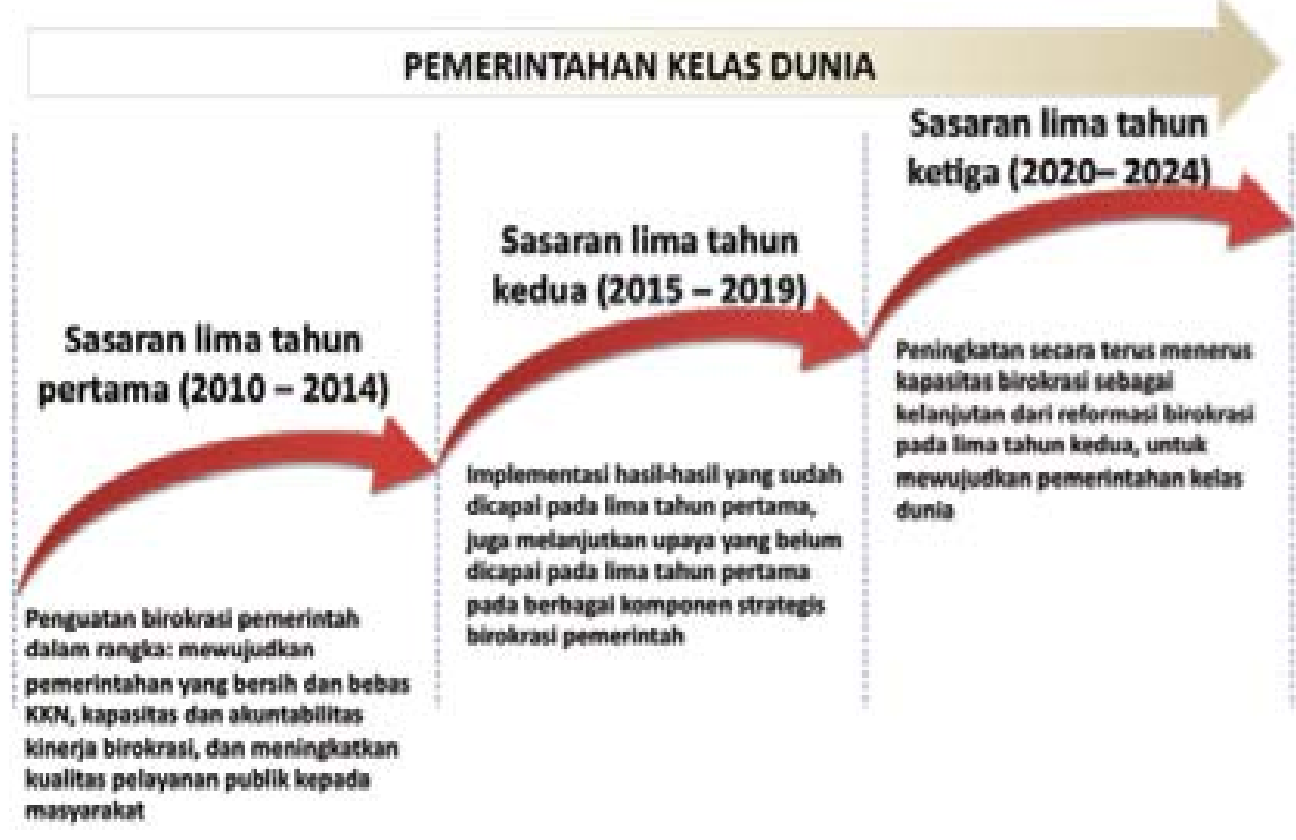

Gambar 2

Grand Design Reformasi Birokrasi menuju Pemerintahan Kelas Dunia bagi Pemerintahan di Indonesia (Sumber: Peraturan Presiden RI No. 81 Tahun 2010 tentang Grand Design Reformasi Birokrasi 2010-2025)

Kabupaten Kepulauan Tanimbar di Provinsi Maluku adalah salah satu daerah di Indonesia yang dalam penyelenggaraan sistem pemerintahannya belum mengalami perubahan yang signifikan dalam mewujudkan tata kelola pemerintahan yang baik (good governance). Dalam rangka mewujudkan Good Governance seperti halnya yang diinginkan Pemerintah Kabupaten Kepulauan Tanimbar yang dimuat dalam Rencana Pembangunan Jangka Menengah Daerah (RPJMD) 2017-2022, memiliki Visi Pembangunan, yaitu "Terwujudnya Kabupaten Kepulauan Tanimbar yang Cerdas, Sehat, Berwibawa dan Mandiri" dan salah satu Misinya, yaitu "Mewujudkan tata kelola pemerintahan yang berkarakter melayani, responsif dan akuntabel", maka perlu diterapkannya prinsip-prinsip Good Governance yang sesuai dengan United Nations Development Program (UNDP) oleh Pemerintah Daerah Kabupaten Kepulauan Tanimbar, sehingga dapat membawa perubahan dan kemajuan bagi Kabupaten Kepulauan Tanimbar.
Sedangkan Road Map Reformasi Birokrasi di Lingkungan Pemerintah Kabupaten Kepulauan Tanimbar diketahui untuk pertama kalinya dan juga menjadi terakhir dilaksanakan pada 2013-2017 yang diatur dalam Peraturan Bupati Maluku Tenggara Barat No. 43 Tahun 2013 tentang Road Map Reformasi Birokrasi di Lingkungan Pemerintah Kabupaten Maluku Tenggara Barat Tahun 2013-2017. Seharusnya penyusunan Road Map Reformasi Birokrasi di Kabupaten Kepulauan Tanimbar dilakukan dengan beberapa tahapan, di antaranya Road Map Reformasi Birokrasi 2010-2014, Road Map Reformasi Birokrasi 2015-2019 dan Road Map Reformasi Birokrasi 2020-2024. yang di mana tertinggal 5 (lima) tahun terakhir, yakni pada 2020-2024 dengan tujuan dan sasaran, yaitu menuju pemerintahan kelas dunia (world class government) dengan menerapkan Dynamic Governance.

Penyusunan Road Map Reformasi Birokrasi 2020-2024 di Kabupaten Kepulauan Tanimbar belum terlaksana karena Peraturan Daerah terkait Road 
Map Reformasi Birokrasi di Lingkungan Pemerintah Kabupaten Kepulauan Tanimbar sebagai tindak lanjut dari Peraturan Presiden Republik Indonesia No. 81 Tahun 2010 tentang Grand Design Reformasi Birokrasi 2010-2025 dan Peraturan Menteri Pendayagunaan Aparatur Negara dan Reformasi Birokrasi Republik Indonesia No. 25 Tahun 2020 tentang Road Map Reformasi Birokrasi 2020-2024 belum dikeluarkan. Keterlambatan yang terjadi disebabkan karena adanya beberapa kendala atau hambatan yang dihadapi pemerintah daerah.

Bagian Organisasi dan Tata Laksana Sekretariat Daerah Kabupaten Kepulauan Tanimbar sebagai Organisasi Perangkat Daerah yang memiliki tugas pokok dan fungsi dalam menyusun Road Map Reformasi Birokrasi kiranya dapat segera membentuk tim penyusunan guna menjalankan visi, misi, tujuan dan sasaran yang ingin dicapai Pemerintah Daerah melalui Road Map Reformasi Birokrasi 2020-2024.

Selain belum dibentuknya tim penyusunan Road Map Reformasi Birokrasi 2020-2024, Bagian Organisasi dan Tata Laksana Sekretariat Daerah Kabupaten Kepulauan Tanimbar juga mengalami beberapa kendala dalam menyusun Road Map Reformasi Birokrasi 2020-2024, di antaranya adalah belum adanya tanggapan yang serius dari pimpinan Organisasi Perangkat Daerah, belum terbentuknya tim reformasi, tim koordinasi dan tim pelaksana, serta terhambatnya penyediaan data oleh Organisasi Perangkat Daerah sebagai data primer yang harus digunakan seperti informasi terhadap laporan kinerja dan Indikator Kinerja Utama.

Road Map Reformasi Birokrasi 20202024 yang belum tersedia akan menghambat pelaksanaan reformasi birokrasi di Kabupaten Kepulauan Tanimbar. Dalam rangka menyusun Road Map Reformasi Birokrasi 2020-2024, diperlukan kerja sama, partisipasi, komitmen dan dukungan dari semua pihak pemangku kepentingan dan masyarakat dalam penyelenggaraan pemerintahan daerah.

Selain itu, kiranya setiap Organisasi Perangkat Daerah yang ada di Pemerintah Kabupaten Kepulauan Tanimbar dapat menjalankan tugas dan kewajiban dengan penuh rasa tanggung jawab sehingga dalam mewujudkan Good Governance dan mengarah pada Dynamic Governance dan Agile Governance di Kabupaten Kepulauan Tanimbar dapat terealisasikan dan tercapai guna terwujudnya pemerintahan yang lebih baik (better governance) dan pemerintahan kelas dunia (world class government) sesuai dengan visi reformasi birokrasi Pemerintahan Indonesia pada Grand Design Reformasi Birokrasi 2010-2025.

\section{METODE PENELITIAN}

Metode penelitian yang digunakan dalam penelitian ini adalah metode penelitian kualitatif dengan pendekatan deskriptif. Sumber data yang digunakan dalam penelitian ini terdiri dari person, place, dan paper. Data person dalam penelitian ini adalah Pemerintah Daerah Kabupaten Kepulauan Tanimbar, data place adalah Bagian Organisasi dan Tata Laksana Sekretariat Daerah Kabupaten Kepulauan Tanimbar sebagai lokus dalam penelitian ini, dan yang merupakan data paper yang digunakan dalam penelitian ini, yaitu aturan-aturan, dokumen-dokumen, dan laporan-laporan terkait penyusunan Road Map Reformasi Birokrasi dalam mewujudkan World Class Government.

Adapun penentuan informan dalam penelitian ini dengan menggunakan purposive sampling pada informan yang mengerti dan memahami objek yang akan diteliti. Pemilihan purposive sampling sebagai teknik penentuan informan didasarkan pada kebutuhan penulis untuk mendalami masalah terkait penyusunan Road Map Reformasi Birokrasi dalam mewujudkan World Class Government. 
Dalam penelitian ini teknik pengumpulan data yang digunakan oleh penulis adalah teknik wawancara, observasi, dan dokumentasi. Sedangkan teknik analisis data menggunakan teknik analisis yang dikemukakan oleh (Miles dan Huberman dalam Patilima, 2016: 102) yaitu reduksi data, penyajian data, dan verifikasi. Serta metode analisis SWOT menurut (Rangkuti, 2016).

\section{HASIL DAN PEMBAHASAN}

\section{Penyusunan Road Map Reformasi Birokrasi dalam mewujudkan World Class Government di Kabupaten Kepulauan Tanimbar Provinsi Maluku}

Konsep reformasi birokrasi yang akan digunakan untuk menganalisis bagaimana penyusunan Road Map Reformasi Birokrasi dalam mewujudkan World Class Government di Kabupaten Kepulauan Tanimbar adalah konsep yang dikemukakan oleh (David Chinn, dkk, 2015) yang di mana konsep tersebut merupakan konsep World Class Government dengan 5 (lima) Approach.

1. Radically redesign public services to improve quality of service and cost

Hasil pengukuran capaian kinerja sasaran meningkatnya kualitas pelayanan publik di Kabupaten Kepulauan Tanimbar, sebagai berikut.

Tabel 1 Pengukuran Sasaran Meningkatnya Kualitas Pelayanan Publik

\begin{tabular}{|c|c|c|c|c|c|}
\hline \multirow[b]{2}{*}{ No. } & \multirow{2}{*}{$\begin{array}{c}\text { Indikator } \\
\text { Kinerja } \\
\text { Utama }\end{array}$} & \multirow[b]{2}{*}{ Satuan } & \multicolumn{3}{|c|}{ Tahun 2019} \\
\hline & & & Target & $\begin{array}{c}\text { Reali- } \\
\text { sasi }\end{array}$ & $\begin{array}{c}\text { Ca- } \\
\text { paian }\end{array}$ \\
\hline 1 & $\begin{array}{l}\text { I n d e k s } \\
\text { K e p u a - } \\
\text { san Mas- } \\
\text { ya rakat } \\
\text { (IKM) }\end{array}$ & $\begin{array}{l}\text { Nilai In- } \\
\text { t e r v a l } \\
\text { Konver- } \\
\text { si (NIK) }\end{array}$ & 82.70 & 78.79 & 95 \\
\hline
\end{tabular}

Sumber: LAKIP 2019 Kabupaten Kepulauan Tanimbar.
Indeks Kepuasan Masyarakat merupakan evaluasi masyarakat terhadap kualitas pelayanan publik yang merupakan hasil interaksi dari berbagai aspek, yakni sistem pelayanan, Sumber Daya Manusia pemberi pelayanan, strategi dan penerima layanan. Kabupaten Kepulauan Tanimbar pada 2019 mencapai predikat pelayanan dengan predikat sangat baik sebesar 95\%. Adanya kebijakan pemerintah daerah dengan menerapkan sistem pelayanan satu pintu dan pelayanan langsung di tempat di seluruh kecamatan dan desa secara intensif, bertujuan memperpendek pelayanan dan menghindari pelayanan yang berbelit-belit bagi masyarakat.

Akan tetapi, Pemerintah Kabupaten Kepulauan Tanimbar perlu untuk mendesain ulang pelayanan publik secara radikal karena pelayanan yang diberikan belum memenuhi kebutuhan masyarakat secara menyeluruh, perlu memperhatikan kebutuhan publik baik berupa barang maupun jasa sehingga masyarakat mendapatkan kepuasan. Dengan memperhatikan kebutuhan publik dan memberikan pelayan secara prima, maka kinerja pelayanan pada Kabupaten Kepulauan Tanimbar juga dapat mengalami peningkatan ke arah yang lebih baik karena dari segi efisiensi biaya sendiri telah mengalami perubahan yang baik (pelayanan secara gratis).

Hal ini sejalan dengan pendapat dari (Wasistiono, 2017: 226) bahwa "Pemerintah dapat menjadi lebih baik, pemerintah dapat mengerjakan dengan lebih baik, dan pemerintah dapat membuat kehidupan masyarakat menjadi lebih mudah dan menghilangkan berbagai kompleksitas yang tidak diperlukan".

2. Restructure the government's approach to managing public finances: budgeting, investment and revenue and workingcapital management

Pemerintah Daerah Kabupaten Kepulauan Tanimbar perlu melakukan 
penyusunan ulang struktur pendekatan pemerintah dalam mengelola keuangan publik. Menurut (Sinurat dan Panjaitan, 2017: 89) bahwa, keuangan daerah adalah semua hak dan kewajiban daerah dalam rangka penyelenggaraan pemerintahan daerah yang dapat dinilai dengan uang, termasuk segala bentuk kekayaan yang berhubungan dengan hak dan kewajiban daerah. Penyelenggaraan fungsi pemerintahan daerah akan terlaksana secara optimal apabila penyelenggaraan urusan pemerintahan diikuti dengan pemberian sumber-sumber penerimaan yang cukup kepada daerah dengan mengacu pada peraturan perundang-undangan (money follow function).

Dalam rangka mewujudkan capaian kinerja Pemerintah Kabupaten Kepulauan Tanimbar sebagaimana pada dokumen Perjanjian Kinerja Tahun 2019, maka Pemerintah Kabupaten Kepulauan Tanimbar didukung dengan alokasi anggaran belanja

Tabel 2 Realisasi Anggaran per 31 Desember 2019

\begin{tabular}{|c|c|c|c|}
\hline NO & SASARAN & PAGU (Rp) & $\begin{array}{l}\text { REALISASI s.d. } \\
31 \text { Desember } 2019 \\
\text { (Rp) } \\
\end{array}$ \\
\hline 1 & $\begin{array}{l}\text { Meningkatnya kualitas Pendidikan yang } \\
\text { inklusif untuk semua }\end{array}$ & 41.868 .726 .677 & 39.204 .000 .251 \\
\hline 2 & $\begin{array}{l}\text { Meningkatnya kualitas kesehatan seluruh } \\
\text { masyarakat semua usia }\end{array}$ & 56.574 .259 .447 & 46.964 .686 .057 \\
\hline 3 & $\begin{array}{l}\text { Meningkatnya kerukunan hidup antar suku } \\
\text { serta antar inter umat beragama }\end{array}$ & 1.126 .638 .760 & 1.104.553.100 \\
\hline 4 & $\begin{array}{l}\text { Meningkatnya internalisasi nilai adat dan } \\
\text { budaya lokal }\end{array}$ & 810.097 .570 & 446.122 .250 \\
\hline 5 & $\begin{array}{l}\text { Meningkatnya peran serta masyarakat dalam } \\
\text { mendorong pembangunan desa }\end{array}$ & 1.894.303.400 & 1.835.410.502 \\
\hline 6 & Meningkatnya kunjungan wisatawan & 7.614.920.948 & 4.820 .744 .800 \\
\hline 7 & $\begin{array}{l}\text { Meningkatnya kualitas akuntabilitas kinerja } \\
\text { pemerintah daerah }\end{array}$ & 6.575 .318 .823 & 5.720 .035 .749 \\
\hline 8 & $\begin{array}{l}\text { Meningkatnya kualitas pengelolaan keuangan } \\
\text { pemerintah daerah }\end{array}$ & 14.217.851.171 & 13.143.938.488 \\
\hline 9 & Meningkatnya kualitas pelayanan publik & 41.956 .234 .876 & 37.245.670.094 \\
\hline 10 & Meningkatnya pertumbuhan ekonomi & 18.327.005.113 & 14.077.079.817 \\
\hline 11 & $\begin{array}{l}\text { Menurunnya } \quad \text { kemiskinan/meningkatkan } \\
\text { kesejahteraan }\end{array}$ & 12.070 .687 .083 & 8.171.234.353 \\
\hline 12 & Menurunnya pengangguran & 952.383 .255 & 880.947 .255 \\
\hline 13 & Terjaganya kualitas lingkungan hidup & 6.306 .542 .910 & 5.692 .602 .942 \\
\hline 14 & $\begin{array}{l}\text { Meningkatnya ketersediaan infrastruktur } \\
\text { terutama di perdesaan untuk mengurangi } \\
\text { kesenjangan antar wilayah }\end{array}$ & 110.046 .261 .255 & 78.248.849.116 \\
\hline & Jumlah & 320.341 .231 .288 & 257.555 .874 .774 \\
\hline
\end{tabular}

Sumber: LAKIP Kabupaten Kepulauan Tanimbar. 2019 
daerah dalam APBD Kabupaten Kepulauan Tanimbar Tahun Anggaran 2019 sebesar Rp320.341.231.288, dengan realisasi sebesar Rp257.555.874.774, -atau 80, 40\%. Hal ini disebabkan terjadinya perubahan APBD pada pertengahan tahun 2018 yang mengakibatkan realisasi tidak sesuai dengan pagu anggaran yang ditetapkan pada awal tahun. Berikut digambarkan rincian anggaran per sasaran strategis sebagaimana pada Tabel 2 di muka.

Dengan demikian, dari segi anggaran perlu dievaluasi agar realisasi penggunaan anggaran sesuai dengan ketersediaan yang ada, memanfaatkan investasi daerah dengan baik, meningkatkan pendapatan asli daerah melalui pajak dan retribusi daerah agar tidak hanya bergantung pada dana transferan dari pusat, dan memperhatikan manajemen modal kerja baik berupa biaya maupun SDM yang ada agar dapat mendukung pelaksanaan reformasi birokrasi berupa penyusunan Road Map Reformasi Birokrasi dalam mewujudkan World Class Government.

\section{Strengthen functional leadership and capabilities across government to support delivery}

Dalam rangka mewujudkan tujuan dan visi reformasi birokrasi, yakni terwujudnya Good Governance dan World Class Government, maka diharapkan Pemerintah Daerah Kabupaten Kepulauan Tanimbar dapat memperkuat dan meningkatkan fungsi kepemimpinan dan kapabilitas melalui kemampuan komersial, pelayanan kepada masyarakat, dan kapabilitas SDM Aparatur. Pemerintah daerah harus mampu berinovasi pada bidang pelayanan publik, mampu menjual keunggulan yang dimiliki oleh daerah sendiri, dan menerapkan manajemen ASN berbasis sistem merit sehingga ASN yang ditempatkan sesuai dengan kemampuannya.

Menurut (Nawawi, 2005: 5) mengungkapkan bahwa pengembangan sumber daya manusia merupakan kegiatan yang harus dilakukan oleh organisasi pemerintah, agar pengetahuan (knowledge), kemampuan (ability) dan keahlian (skill) pegawai sesuai dengan tuntutan pekerjaan yang mereka lakukan. Sedangkan menurut (Schwandt dan Marquardt dalam Sahertian, 2010: 156) mengatakan bahwa, tidak ada peran lain dalam organisasi yang telah menarik begitu banyak perhatian seperti peran pemimpin. Peran pemimpin sangat diperlukan dalam menetapkan tujuan, mengalokasikan sumber daya yang langka, memfokuskan perhatian pada tujuan perusahaan, mengoordinasikan perubahan yang terjadi, membina kontak antar pribadi dengan pengikutnya, dan menetapkan arah yang benar atau yang paling baik bila kegagalan terjadi.

\section{Optimize the government's structure, scale and operating model}

Pemerintah Kabupaten Kepulauan Tanimbar perlu melakukan evaluasi dan pembenahan dengan cara mengoptimalkan struktur organisasi, skala prioritas dan model operasi pemerintah daerah. Menurut (Negandhi, 1975 dalam Suryaningsum, 2008: 67) menyatakan, untuk membuat struktur organisasi yang tepat, dimulai dari melihat karakteristik fenomena birokrasi, dilakukan riset untuk mempelajari organisasi yang kompleks yang dapat menjelaskan sebabsebab adanya struktur khusus dan mencari konsekuensi dari struktur-struktur khusus tersebut pada pola-pola perilaku dan efektivitas dari sebuah organisasi.

Struktur organisasi di Kabupaten Kepulauan Tanimbar yang masih banyak atau gemuk membuat sehingga adanya tumpang tindih dalam pelaksanaan tugas dan tanggung jawab. Untuk itu, perlu perampingan dalam struktur organisasi, mengutamakan apa yang menjadi skala prioritas daerah, dan menjalankan rencana pemerintah daerah sesuai dengan model operasi dalam penyusunan Road Map Reformasi Birokrasi 2020-2024 di Kabupaten Kepulauan Tanimbar. 
5. Develop the vision, accountability and capabilities needed to drive a large-scale transformation

Pemerintah Kabupaten Kepulauan Tanimbar selaku pengemban amanat masyarakat Kabupaten Kepulauan Tanimbar, melaksanakan kewajiban berakuntabilitas melalui penyajian Laporan Kinerja Pemerintah Kabupaten Kepulauan Tanimbar yang dibuat sesuai ketentuan yang diamanatkan dalam Peraturan Presiden No. 29 Tahun 2014 tentang Sistem Akuntabilitas Kinerja Instansi Pemerintah dan Peraturan Menteri Negara Pendayagunaan Aparatur Negara dan Reformasi Birokrasi RI No. 53 Tahun 2014 tentang Petunjuk Teknis Perjanjian Kinerja, Pelaporan Kinerja dan Tata Cara Review Atas Laporan Kinerja Instansi Pemerintah.

Laporantersebutmemberikan gambaran penilaian tingkat pencapaian target masingmasing indikator sasaran strategis yang ditetapkan dalam dokumen RPJMD Tahun 2017-2022. Sesuai dengan ketentuan tersebut, pengukuran kinerja digunakan untuk menilai keberhasilan dan kegagalan pelaksanaan kegiatan sesuai dengan program, sasaran yang ditetapkan untuk mewujudkan visi dan misi pembangunan Pemerintah Kabupaten Kepulauan Tanimbar. Berikut adalah skala nilai peringkat kinerja.

Tabel 3 Skala Nilai Peringkat Kinerja

\begin{tabular}{ccl}
\hline No. & $\begin{array}{c}\text { Interval Nilai } \\
\text { Realisasi Kinerja }\end{array}$ & $\begin{array}{c}\text { Kriteria Penilaian } \\
\text { Realisasi Kinerja }\end{array}$ \\
\hline 1 & $91 \geq$ & Sangat Tinggi \\
2 & $76 \leq 90$ & Tinggi \\
3 & $66 \leq 75$ & Sedang \\
4 & $51 \leq 65$ & Rendah \\
5 & $\leq 50$ & Sangat Rendah \\
\hline
\end{tabular}

Sumber: LAKIP 2019 Kabupaten Kepulauan Tanimbar.

Pemerintah Kabupaten Kepulauan Tanimbar harus berupaya dalam mengembangkan visi, akuntabilitas dan kapabilitas yang dibutuhkan daerah agar dapat mendorong terjadinya transformasi menuju pemerintahan kelas dunia. Hal ini sejalan dengan pendapat yang dikemukakan oleh (Wasistiono, 2017: 220) bahwa, untuk mencapai pemerintahan kelas dunia, para pemimpin pemerintahan dituntut untuk melakukan transformasi, bukan hanya sekadar pembangunan. Pembangunan lebih bersifat menciptakan yang belum ada atau memperbaiki yang sudah ada agar menjadi lebih baik, sedangkan transformasi lebih mengarah pada perubahan bentuk, penampilan, kinerja agar sesuai dengan perkembangan jaman.

Keadaan yang terjadi di lapangan, pemerintah daerah belum memiliki satu persepsi dan sepenuhnya menjalankan tugas dan tanggung jawab sesuai dengan visi daerah, akuntabilitas dan kapabilitas SDM Aparatur masih harus ditingkatkan lagi melalui penataan manajemen ASN berbasis sistem merit sehingga mampu menyiapkan diri dan membentuk tim penyusunan Road Map Reformasi Birokrasi. Dengan demikian, pelaksanaan reformasi birokrasi menuju pemerintahan kelas dunia dan Good Governance dapat terwujud di Kabupaten Kepulauan Tanimbar.

\section{Faktor pendukung dan faktor penghambat penyusunan Road Map Reformasi Birokrasi dalam mewujudkan World Class Government di Kabupaten Kepulauan Tanimbar Provinsi Maluku}

Faktor pendukung penyusunan Road Map Reformasi Birokrasi dalam mewujudkan World Class Government di Kabupaten Kepulauan Tanimbar sebagai berikut.

\section{Sumber Daya Manusia}

Hasil penelitian menunjukkan bahwa Sumber Daya Manusia sangat memadai dan dapat berguna bagi masingmasing Organisasi Perangkat Daerah 
di Kabupaten Kepulauan Tanimbar dalam membantu mencapai tujuan organisasinya tersebut.

2. Transparansi Pemerintahan dan Supremasi Hukum

Hasil penelitian menunjukkan bahwa transparansi pemerintahan dan supremasi hukum sangat penting dalam mendukung Pemerintah Daerah Kabupaten Kepulauan tanimbar melaksanakan reformasi birokrasi dan mewujudkan World Class Government, karena berhasil atau tidaknya suatu daerah juga dapat dinilai dari hal tersebut.

3. Pedoman berupa Peraturan/Regulasi

Di Kabupaten Kepulauan Tanimbar, salah satu pedoman peraturan yang ada, yakni Peraturan Menteri PAN RB No. 25 Tahun 2020 tentang Road Map Reformasi Birokrasi 2020-2024. Dengan adanya pedoman berupa peraturan ini, maka Pemerintah Daerah Kabupaten Kepulauan Tanimbar dapat menindaklanjutinya dengan Peraturan Bupati terkait penyusunan Road Map Reformasi Birokrasi 2020-2024 yang dimaksud.

4. Partisipasi Masyarakat

Hasil penelitian menunjukkan bahwa masyarakat di Kabupaten Kepulauan Tanimbar ikut berpartisipasi dalam memperhatikan penyelenggaraan sistem pemerintahan berupa memberikan kritikan dan masukan melalui kotak saran atau sosial media, serta mengikuti kegiatan dan kebijakan yang dikeluarkan pemerintah daerah.

5. Dukungan dari Stakeholder

Dukungan dari Stakeholder dinilai baik dan sangat membantu pemerintah daerah. Hal ini dikarenakan semua elemen yang ada di Kabupaten Kepulauan Tanimbar sangat mengharapkan perubahan yang terjadi menuju ke arah yang lebih baik terkhususnya pada peningkatan kualitas pelayanan publik.

Adapun faktor penghambat penyusunan Road Map Reformasi Birokrasi dalam mewujudkan World Class Government di Kabupaten Kepulauan Tanimbar sebagai berikut.

1. Komitmen

Hasil penelitian menunjukkan bahwa walaupun Kabupaten Kepulauan Tanimbar mempunyai Sumber Daya Manusia Aparatur yang cukup memadai, namun dari SDM Aparatur yang ada tidak semua dapat berkomitmen untuk tetap menjalankan tupoksinya masing-masing dengan baik dan tetap bersama-sama pada satu tujuan, yaitu melaksanakan reformasi birokrasi dalam mewujudkan World Class Government.

2. Etika, Kompetensi dan Kapabilitas ASN

Etika, kompetensi dan kapabilitas ASN merupakan salah satu faktor penghambat internal penyusunan Road Map Reformasi Birokrasi dalam mewujudkan World Class Government di Kabupaten Kepulauan Tanimbar karena masih terdapat ASN di Kabupaten Kepulauan Tanimbar yang belum memiliki ketiga hal tersebut dalam diri pribadi masingmasing sehingga belum terwujudnya pemerintahan yang baik.

3. Keterbatasan Modal Kerja dan Modal Operasional

Hasil penelitian menunjukkan bahwa Kabupaten Kepulauan Tanimbar dalam pelaksanaan reformasi birokrasi mengalami kendala, yakni keterbatasan anggaran sehingga program belum berjalan lancar sesuai rencana.

4. Penyesuaian dan Sinkronisasi Program Hasil penelitian menunjukkan bahwa penyesuaian dan sinkronisasi program dengan kegiatan pendukung pelaksanaan Road Map Reformasi Birokrasi belum ada. 


\section{Sarana Prasarana}

Hasil penelitian menunjukkan bahwa perlu dilengkapinya fasilitas sarana prasarana yang ada di Kabupaten Kepulauan Tanimbar karena dinilai belum lengkap dan belum menunjang kegiatan atau program yang ada.

6. Persepsi atau Pola Pikir Masyarakat

Hasil penelitian menunjukkan bahwa perlu adanya campur tangan dari Pemerintah Daerah Kabupaten Kepulauan Tanimbar berupa pemberian sosialisasi terhadap masyarakat, melibatkan masyarakat dalam beberapa urusan pemerintahan, pemerintahan yang bersifat transparansi dan akuntabel, serta memberikan pelayanan secara prima sesuai dengan aturan yang berlaku.

7. Kurangnya Dukungan dari Pelaku Usaha Hasil penelitian menunjukkan bahwa masih terdapat beberapa pelaku usaha yang belum sepenuhnya mendukung pemerintah daerah. Hal ini seharusnya menjadi perhatian pemerintah daerah agar lebih memperhatikan dan menjadi bahan evaluasi untuk membangun kerja sama dan melakukan koordinasi dengan pihak pelaku usaha.

\section{Strategi yang dapat dilakukan oleh Pemerintah Daerah Kabupaten Kepulauan Tanimbar untuk menyusun Road Map Reformasi Birokrasi dalam mewujudkan World Class Government}

Setelah diidentifikasi kekuatan (Strengths), kelemahan (weakness), peluang (opportunities) dan ancaman (threat) dalam organisasi khususnya pada proses penyusunan Road Map Reformasi Birokrasi dalam mewujudkan World Class Government, dan berdasarkan perumusan strategi dengan menggunakan metode analisis SWOT, maka adapun strategi yang didapatkan antara lain sebagai berikut.
1. Memanfaatkan potensi yang sudah ada baik itu dari potensi Sumber Daya Alam maupun Sumber Daya Manusia, khususnya ASN yang sudah memadai dan siap dalam menunjang pelaksanaan tugas-tugas birokrasi pada Kabupaten Kepulauan Tanimbar; dan

2. Memanfaatkan perhatian Pemerintah Pusat dan Provinsi terhadap pembangunan Blok Masela. Dengan adanya pembangunan Blok Masela dapat membuka lapangan pekerjaan, peningkatan perekonomian dan pembangunan daerah dapat lebih maju di Kabupaten Kepulauan Tanimbar.

\section{SIMPULAN}

Adapun beberapa simpulan sebagai berikut.

1. Penyusunan Road Map Reformasi Birokrasi dalam mewujudkan World Class Government di Kabupaten Kepulauan Tanimbar Provinsi Maluku belum terlaksana. Hal ini dikarenakan belum adanya peraturan daerah/bupati terkait Road Map Reformasi Birokrasi 2020-2024 dan adanya ego sektoral antar Organisasi Perangkat Daerah. Ditinjau dari kelima pendekatan dalam mencapai World Class Government, Pemerintah Daerah Kabupaten Kepulauan Tanimbar belum sepenuhnya menjalankan atau mencapai target dari masing-masing pendekatan tersebut. Masih perlu perhatian dan kerja keras pemerintah daerah dalam menangani permasalahan dimaksud. Dengan demikian, Kabupaten Kepulauan Tanimbar masih jauh dari upaya mencapai World Class Government.

2. Faktor pendukung penyusunan Road Map Reformasi Birokrasi dalam mewujudkan World Class Government di Kabupaten Kepulauan Tanimbar Provinsi Maluku, antara lain: Sumber Daya Manusia, Transparansi Pemerintahan dan Supremasi Hukum, 
adanya Pedoman berupa Peraturan/ Regulasi, Partisipasi Masyarakat, Dukungan dari Stakeholder. Sedangkan faktor penghambat yaitu Komitmen, Etika, Kompetensi dan Kapabilitas ASN, Keterbatasan Modal Kerja dan Modal Operasional, Penyesuaian dan Sinkronisasi Program, Sarana Prasarana, Persepsi atau Pola Pikir Masyarakat, dan masih kurangnya Dukungan dari Pelaku Usaha.

3. Strategi yang dapat dilakukan oleh Pemerintah Daerah Kabupaten Kepulauan Tanimbar untuk menyusun Road Map Reformasi Birokrasi dalam mewujudkan World Class Government, sebagai berikut.

- Memanfaatkan potensi sumber daya, yakni ASN yang sudah memadai dan siap dalam menunjang pelaksanaan tugas-tugas birokrasi; dan

- Memanfaatkan perhatian Pemerintah Pusat dan Provinsi terhadap pembangunan Blok Masela.

\section{SARAN}

Berdasarkan simpulan dari hasil penelitian di atas, maka penulis mengajukan beberapa saran sebagai berikut.

1. Pemerintah Daerah kiranya segera mengeluarkan peraturan daerah/bupati terkait Road Map Reformasi Birokrasi 2020-2024 yang mengacu pada Peraturan Menteri PAN RB No. 25 Tahun 2020, sehingga dapat menyusun Road Map Reformasi Birokrasi 2020-2024 di Kabupaten Kepulauan Tanimbar. Selain itu, perlu menghilangkan sifat ego sektoral antar Organisasi Perangkat Daerah agar dapat bekerja sama meningkatkan kinerja organisasi dalam pelaksanaan reformasi birokrasi. Dan pada kelima pendekatan World Class Government, perlu diperhatikan dan direalisasikan di daerah karena masing- masing pendekatan belum sepenuhnya terpenuhi. Dengan mewujudkan hal tersebut, maka pemerintah daerah dapat mencapai visi reformasi birokrasi Pemerintahan Indonesia, yaitu "Terwujudnya Pemerintahan Kelas Dunia" dan tujuan reformasi birokrasi "Mewujudkan Tata Kelola Pemerintahan yang Baik".

2. Faktor pendukung yang perlu dimanfaatkan dengan maksimal adalah Sumber Daya Manusia (ASN). Dengan adanya Sumber Daya Manusia yang memadai, maka dapat menunjang pelaksanaan reformasi birokrasi. Untuk itu perlu menerapkan manajemen ASN berbasis sistem merit, menyusun standar kompetensi jabatan sebagai basis assessment pegawai, dan melaksanakan penilaian kinerja individu aparatur secara objektif. Sedangkan faktor penghambat perlu untuk diminimalkan dengan membangun kerja sama yang baik lintas sektor yang terlibat dalam penyusunan Road Map Reformasi Birokrasi 2020-2024 di Kabupaten Kepulauan Tanimbar.

3. Pemerintah daerah agar melihat peluang untuk memanfaatkan sumber daya yang ada dan memadai dalam menunjang pelaksanaan reformasi birokrasi. Selain itu, pemerintah daerah juga harus membangun koordinasi yang baik dengan pemerintah pusat maupun provinsi dalam pembangunan Blok Masela. Dengan demikian, dapat menjadi keuntungan bagi kemajuan daerah Kabupaten Kepulauan Tanimbar.

\section{DAFTAR RUJUKAN}

Chinn, David, J. Dimson, A. Goodman, dan I. Gleeson. 2015. World-Class GovernmentTransforming the UK Public Sector in an Era of Austerity: Five Lessons from Around the World. Discussion paper. McKinsey \& Company. 
Ilham, M. dan Annisa Rahmadanita. 2019. Modul Mata Kuliah Birokrasi. FHTP IPDN: Jatinangor.

Nawawi, H. Hadari. 2005. Perencanaan SDM. Gajah Mada Univ. Press: Yogyakarta.

Patilima, Hamid. 2016. Metode Penelitian Kualitatif Edisi Revisi. Alfabeta: Bandung.

Rangkuti, Freddy. 2016. Teknik Membedah Kasus Bisnis Analisis SWOT. PT Gramedia Pustaka Utama: Jakarta.

Sahertian, Pieter. 2010. Perilaku Kepemimpinan Berorientasi Hubungan dan Tugas sebagai Anteseden Komitmen Organisasional, SelfEfficacy dan Organizational Citizenship Behavior (OCB). Jurnal Manajemen dan Kewirausahaan, Volume 12, No. 2, Hal. 156-169.

Sinurat, Marja dan Horas M. Panjaitan. 2017. Perencanaan dan Penganggaran Daerah. Pustaka Rahmat: Bandung.

Suryaningsum, Sri. 2008. Perspektif Struktur Organisasi (Tinjauan sebagai Pengubah Perilaku). Jurnal Pendidikan Akuntansi Indonesia, Volume VI, No. 1, Hal. 63-74.

Wasistiono, Sadu. 2017. Perkembangan Ilmu Pemerintahan (dari Klasik sampai ke Kontemporer). IPDN Press: Jatinangor.

Wasistiono, Sadu and Wike Anggraini. 2019. Three Paradigms in Government (Good Governance, Dynamic Governance, and Agile Governance). International Journal of Kybernology, Volume 4, Number 2, Hal. 79-91: Jatinangor.

\section{Peraturan Perundang-Undangan}

Peraturan Presiden Republik Indonesia No. 81 Tahun 2010 tentang Grand Design Reformasi Birokrasi 2010-2025.

Peraturan Presiden Republik Indonesia No. 29 Tahun 2014 tentang Sistem Akuntabilitas Kinerja Instansi Pemerintah.

Peraturan Menteri Pendayagunaan Aparatur Negara dan Reformasi Birokrasi Republik Indonesia No. 53 Tahun 2014 tentang Petunjuk Teknis Perjanjian Kinerja, Pelaporan Kinerja dan Tata Cara Review atas Laporan Kinerja Instansi Pemerintah.

Peraturan Menteri Pendayagunaan Aparatur Negara dan Reformasi Birokrasi Republik Indonesia No. 25 Tahun 2020 tentang Road Map Reformasi Birokrasi 20202024.

Peraturan Bupati Maluku Tenggara Barat No. 43 Tahun 2013 tentang Road Map Reformasi Birokrasi di Lingkungan Pemerintah Kabupaten Maluku Tenggara Barat Tahun 2013-2017.

Road Map Reformasi Birokrasi 2015 - 2019

Rencana Pembangunan Jangka Menengah Daerah Kabupaten Kepulauan Tanimbar Tahun 2017-2022

Laporan Akuntabilitas Kinerja Instansi Pemerintah Kabupaten Kepulauan Tanimbar Tahun 2019 
Visioner ! Vol. $13 \backslash$ No. 3\Desember 2021 